\title{
KOMPOSISI JENIS DAN REGENERASI ALAMI MANGROVE DI BKPH UJUNG-KRAWANG, KPH BOGOR, JAWA BARAT
}

\author{
Species Composition and Natural Regeneration of Mangrove at BKPH Ujung-Krawang, \\ KPH Bogor, West Java
}

\section{Cecep Kusmana $^{1 *}$ dan Yustika Siregar ${ }^{2}$}

(Diterima April 2018/Disetujui Juni 2020)

\begin{abstract}
The mangrove forests in BKPH Ujung-Krawang is a protected forest that has been degraded by human activities. This study aims to identifying the species composition and elucidating the structure and regeneration mangrove forests in BKPH Ujung-Krawang, KPH Bogor, West Java. This research carries out in two location (Muara Gembong and RPH RPH Singkil), with the condition of mangrove forests are degraded due to the forest conversion into fishpond, fish farming, and housing areas on large scale. Mangrove forest composition consisted by api-api (Avicennia sp.), pedada (Sonneratia sp.) and buta-buta (Excoecaria agallocha). Based on observation, mangrove forests regeneration in RPH Muara Gembong categorized as "good "caused number of seedlings is more than sapling and "fair" in RPH Singkil caused number trees is greater than the level of the regeneration (sapling and seedling).
\end{abstract}

Keywords: KPH Bogor, mangrove forest, natural regeneration, species composition, Ujung-Krawang

\section{PENDAHULUAN}

Hutan mangrove merupakan suatu tipe hutan yang khas dengan ekosistem yang unik serta merupakan salah satu sumberdaya alam yang sangat potensial dan merupakan perpaduan antara unsur fisik, biologi daratan dan lautan, sehingga menciptakan keterkaitan suatu ekosistem daratan dan lautan. Hutan mangrove tumbuh di sepanjang garis pantai dalam 257 kabupaten/kota yang ada di Indonesia. Bakosurtanal (2009) dalam Kusmana (2014) melaporkan bahwa luasan mangrove Indonesia berkisar 3.2 jua ha. Namun, data berdasarkan Kementerian Kehutanan (2007) dalam Kusmana (2014) sekitar 7.8 juta ha area yang sangat potensial untuk penanaman mangove, dimana $30.7 \%$ kondisi baik, $27.4 \%$ rusak, dan $41.9 \%$ rusak berat.

Kondisi mangrove yang rusak tersebut, dikhawatirkan akan berdampak pada menurunnya kemampuan mangrove dalam menjalankan fungsinya. Fungsi sosio-ekonomi hutan mangrove, diantaranya berupa hasil hutan kayu dan hasil hutan bukan kayu seperti madu, obat-obatan dan minuman. Fungsi ekologis dari hutan mangrove yaitu sebagai tempat mencari makan, tempat berpijah, tempat berlindung berbagai spesies biota perairan payau.

Badan Kesatuan Pemangkuan Hutan UjungKrawang adalah satu-satunya BKPH di KPH Bogor yang mengelola hutan mangrove dan termasuk ke dalam kawasan hutan lindung sebagaimana yang ditetapkan

${ }^{1}$ Staf Pengajar Departemen Silvikultur, Fakultas Kehutanan dan Linkungan Institut Pertanian Bogor

* Penulis korespondensi: e-mail: ckmangrove@gmail.com

${ }^{2}$ Mahasiswa Departemen Silvikultur, Fakultas Kehutanan Institut Pertanian Bogor oleh Menteri Pertanian RI pada tahun 1954 melalui SK Nomor 92/UM/54. Kondisi hutan mangrove di BKPH Ujung Krawang ini mengalami berbagai tekanan seperti okupasi lahan, konversi lahan, yang merupakan permasalahan utama dalam pengelolaan hutan tersebut. Sebagian besar dari hutan telah dikonversi menjadi tambak, kebun dan bahkan menjadi pemukiman penduduk setempat. Apabila degradasi ini terus berlanjut, maka akan terjadi kerusakan kuantitas dan kualitas ekosistem pesisir yang berimplikasi pada penurunan fungsi lingkungan dari mangrove tersebut. Oleh karena itu perlu dikaji mengenai komposisi jenis pohon dan regenerasi alami hutan mangrove di BKPH UjungKrawang KPH Bogor untuk memberikan gambaran mengenai kondisi hutan mangrove tersebut. Penelitian ini bertujuan untuk mengidentifikasi perubahan komposisi jenis regenerasi hutan mangrove di BKPH UjungKrawang, KPH Bogor, Jawa Barat.

\section{METODE PENELITIAN}

\section{Lokasi dan Waktu Penelitian}

Penelitian dilaksanakan selama 2 bulan yaitu dari bulan April-Mei 2016. Penelitian ini dilakukan di kawasan mangrove BKPH Ujung Krawang KPH Bogor, Jawa Barat.

\section{Alat dan Bahan}

Alat yang digunakan dalam penelitian ini adalah meteran jahit, pita ukur (phiband), Hagahypsometer, kompas, plastik bening, tali rafia, golok, laptop, tally sheet, alat tulis, kamera, dan perangkat komputer seperti Microsoft Word, Miscrosoft Excel, dan termometer. Bahan utama yang diperlukan adalah vegetasi mangrove 
di RPH Muara Gembong dan RPH Singkil, BKPH Ujung Krawang, KPH Bogor, Jawa Barat.

\section{Pengambilan Data}

Peletakan unit contoh (desain sampling) yang digunakan dalam penelitian ini adalah systematic sampling with random start yaitu jalur pertama dilakukan secara acak dan selanjutnya dengan penentuan jalur secara berurutan. Jalur-jalur contoh ini dibuat tegak lurus dengan sungai atau saluran drainase agar jalur contoh tersebut dapat mencakup perubahan komposisi vegetasi mulai dari sungai sampai ke pedalaman (Kusmana 1997). Teknik analisis vegetasi yang menggunakan metode dengan petak yaitu kombinasi antara metode jalur dengan metode garis berpetak, perisalahan pohon dilakukan dengan metode jalur dan permudaan dengan metode garis berpetak.

\section{Analisis Data}

\section{Indeks Nilai Penting (INP)}

Nilai indeks nilai penting (INP) digunakan untuk mengetahui komposisi jenis suatu tegakan (Indriyanto 2005).

INP untuk tingkat pohon:

$$
\mathrm{INP}=\mathrm{KR}+\mathrm{FR}+\mathrm{DR}
$$

INP untuk semi dan pancang:

$$
\mathrm{INP}=\mathrm{KR}+\mathrm{FR}
$$

$$
\begin{array}{ll}
\text { Kerapatan } & \left.=\frac{\text { Jumlah individu suatu jenis }}{\text { Luas petak contoh }} \text { (ind } / \mathrm{ha}\right) \\
\text { Kerapatan Relatif } & =\frac{\text { Kerapatan suatu jenis }}{\text { Kerapatan seluruh jenis }} \times 100 \% \\
\text { Frekuensi } & =\frac{\text { Jumlah plot ditemukan suatu jenis }}{\text { Jumlah seluruh plot }} \\
\text { Frekuensi Relatif } & =\frac{\text { Frekuensi suatu jenis }}{\text { Frekuensi seluruh jenis }} \times 100 \% \\
\text { Dominansi } & =\frac{\text { Jumlah LBDS suatu jenis }}{\text { Luas petak contoh }}\left(\mathrm{m}^{2} / \mathrm{ha}\right) \\
\text { Dominansi Relatif } & =\frac{\text { Dominansi suatu jenis }}{\text { Dominansi seluruh jenis }} \times 100 \%
\end{array}
$$

\section{Indeks Dominansi Jenis (C)}

Indeks Dominansi Jenis bertujuan untuk mengetahui penguasaan suatu jenis pada suatu areal dengan rumus (Simpson 1949 dalam Mirsa 1980) sebagai berikut:

$$
\mathrm{C}=\sum_{t=1}^{n}\left(\frac{\mathrm{n}_{\mathrm{t}}}{\mathrm{N}}\right)^{2}
$$

Keterangan:

$\mathrm{C}=$ Indeks dominansi jenis

$\mathrm{n}_{\mathrm{t}} \quad=$ kerapatan jenis ke- $\mathrm{i}$

$\mathrm{N}=$ total kerapatan

\section{Indeks Keanekaragaman Jenis (H')}

Indeks keanekaragaman jenis (H') dihitung menggunakan rumus Shannon (Magurran 1988) sebagai berikut:

$$
\mathrm{H}^{\prime}=-\sum_{\mathrm{i}} \frac{\mathrm{ni}}{\mathrm{N}} \ln \left(\frac{\mathrm{ni}}{\mathrm{N}}\right)
$$

Keterangan:

$\mathrm{H}^{\prime}=$ Indeks keanekaragaman jenis Shannon

$\mathrm{ni}=$ nilai kerapatan jenis ke-i

$\mathrm{N}=$ total kerapatan

\section{Indeks Kekayaan Jenis (R)}

Perhitungan indeks kekayaan jenis menggunakan rumus Margallef (Ludwig dan Reynold 1988), yaitu :

Dimana;

$$
R=\frac{(S-1)}{\ln (N)}
$$

R1 = Indeks Kekayaan jenis Margalef

$\mathrm{S}=$ Jumlah jenis yang ditemukan

$\mathrm{N}=$ Jumlah total individuln $(\mathrm{N})$

Terdapat tiga kriteria untuk nilai indeks kekayaan jenis, yaitu rendah jika nilai $\mathrm{R}<3.5$, sedang jika nilai $\mathrm{R}$ $=3.5$ - 5.0 dan tinggi jika nilai $R>5.0$ (Magurran 1998).

\section{Indeks Kemerataan Jenis (E)}

Semakin tinggi nilai E maka nilai kemerataannya akan semakin tinggi, rumusnya adalah sebagai berikut:

Dimana;

$$
E=\frac{H^{\prime}}{\ln (S)}
$$

$\mathrm{E}=$ Indeks kemerataan jenis

$\mathrm{H}^{\prime}=$ Indeks keanekaragaman jenis

$\mathrm{S}=$ Jumlah jenis

\section{Struktur Tegakan}

Struktur tegakan yang diamati dalam penelitian ini berupa struktur vertikal (stratifikasi tajuk) dan struktur horizontal (sebaran diameter pohon). Cara untuk mengetahui struktur vertikal hutan yaitu, setiap individu pohon yang ditemukan di dalam petak ukur dikelompokkan berdasarkan kelas tinggi atau lapisan stratum. Menurut Soerianegara dan Indrawan (1998), lapisan stratum terdiri dari stratum A (> 30 meter), stratum B (20 - 30 meter), stratum C (4 - 20 meter),

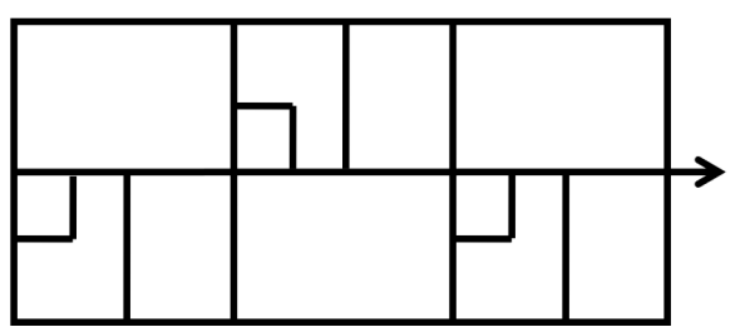

Keterangan: sub petak $2 \mathrm{~m}$ x $2 \mathrm{~m}$ untuk pengamatan permudaan tingkat seedling (semai), sub petak $5 \mathrm{~m}$ x $5 \mathrm{~m}$ untuk pengamatan permudaan tingkat sapling (pancang) dan sub petak $10 \mathrm{~m} \times 10 \mathrm{~m}$ digunakan untuk pengamatan pohon.

Gambar 1 Petak contoh untuk analisis vegetasi 
stratum D ( $1-4$ meter $)$ dan stratum E $(0-1$ meter $)$ Struktur horizontal untuk mengetahui penyebaran diameter pohon di hutan, maka setiap individu yang ditemukan di dalam petak ukur dikelompokkan berdasarkan kelas diameter. Dalam penelitian ini disusun sebaran pohon untuk dalam 6 kelas diameter yaitu $10-$ $20 \mathrm{~cm}, 21-30 \mathrm{~cm}, 31-40 \mathrm{~cm}, 41-50 \mathrm{~cm}, 51-60 \mathrm{~cm}$, dan lebih dari $60 \mathrm{~cm}$ ke atas.

\section{Status Regenerasi}

Shankar (2001) status regenerasi hutan dikelompokkan menjadi lima yaitu: 1) baik (good) apabila jumlah semai > pancang > pohon, 2) cukup/sedang (fair) apabila jumlah semai> pancang < pohon, 3) rendah (poor) apabila jenis yang dapat bertahan hanya pada tingkat pertumbuhan pancang tetapi tidak pada tingkat semai atau dengan jumlah pancang lebih besar atau lebih rendah bahkan sama dengan pohon, 4) tidak ada regenerasi (none) apabila tidak ada jenis yang ditemukan pada tingkat semai maupun pancang, dan 5) baru beregenerasi (new) apabila tidak ditemukannya jenis pada tingkat pohon tetapi hanya pada tingkat semai dan pancang

\section{HASIL DAN PEMBAHASAN}

\section{Kondisi Umum Lokasi Penelitian}

Badan Kesatuan Pemangkuan Hutan (BKPH) Ujung-Krawang adalah bagian dari kesatuan kerja KPH Bogor, secara geografis terletak di antara 10700'03" 10706'00" BT dan 0555'00" - 0605'30' LS. Secara administratif berada di wilayah Kabupaen Bekasi, Jawa Barat dan berada di pantai Utara Pulau Jawa. BKPH Ujung-Krawang terbagi menjadi tiga Resort Pemangkuan Hutan (RPH) yaitu, RPH Muara Gembong seluas 2.439,75 ha, RPH Singkil seluas 3.318,50 ha, dan RPH Pondok Tengah seluas 4.722,90 ha.

Jenis tanah di hutan mangrove BKPH UjungKrawang berdasarkan klasifikasi USDA adalah Hydraquents dengan warna tanah abu-abu, tekstur tanah yaitu Sandy loam (lempung berpasir) dan liat (Clay), kelengketan mulai dari agak lengket sampai dengan sangat lengket dan plastisitas mulai dari tidak plastis sampai dengan sangat plastis. Ketinggian tempat lokasi penelitian berkisar antara $0-75$ mdpl dengan kemiringan lereng antara $0-8 \%$. Tipe iklim di kawasan hutan BKPH Ujung-Krawang berdasarkan klasifikasi iklim Schmidt dan Ferguson adalah tipe iklim C, dengan curah hujan rata-rata sebesar $1753 \mathrm{~m}$. Suhu udara berkisar antara $23^{\circ} \mathrm{C}$ $-32 \mathrm{C}$, dan kelembaban $77 \%-99 \%$.

\section{Komposisi Jenis}

Jenis-jenis penyusun hutan mangrove yang ditemukan di lokasi penelitian (RPH Muara Gembong dan RPH Singkil) terdapat tiga jenis mangrove, yaitu apiapi (Avicennia sp.), pidada (Sonneratia sp.), dan butabuta (Excoecaria agallocha).

\section{Indeks Nilai Penting (INP)}

Indeks nilai penting digunakan untuk mengetahui dominansi atau penguasaan suatu jenis, yaitu apabila nilai INP suatu jenis tinggi maka akan mengindikasikan jenis tersebut ada jenis jenis yang dominan di suatu lokasi.

\section{Keanekaragaman Jenis (H'), Kekayaan Jenis (R), dan Kemerataan Jenis (E)}

RPH Muara Gembong memiliki keanekaragaman jenis mangrove pada setiap tingkat pertumbuhan adalah rendah $(\mathrm{H}<2)$, sama halnya dengan keanekaragaman jenis, kekayaan jenisnya juga tergolong rendah $(\mathrm{R}<3.5)$. Kemerataan jenisbervariasi yaitu sedang pada tingkat pohon $(\mathrm{H}=0.3)$, tinggi pada tingkat pancang $(\mathrm{H}>0.6)$ dan rendah pada tingkat semai $(\mathrm{H}<0.3)$. Selain itu, keanekaragaman jenis, kekayaan jenis, dan kemerataan jenis yang rendah.

\section{Stuktur Tegakan}

\section{Struktur Horizontal}

Grafik struktur horizontal tingkat pohon di BPKH Ujung-Krawang (Gambar 3) menunjukkan bahwa semakin besar ukuran diameter pohon, maka jumlah

Tabel 1 Indeks Nilai Penting jenis-jenis mangrove pada setiap lokasi pengamatan di BKPH Ujung-Krawang

\begin{tabular}{|c|c|c|c|c|c|}
\hline Nama Lokal & Nama Ilmiah & $\mathrm{K}$ (ind/ha) & $\mathrm{F}$ & $\mathrm{D}\left(\mathrm{m}^{2} / \mathrm{ha}\right)$ & INP (\%) \\
\hline \multicolumn{6}{|c|}{ RPH Muara Gembong } \\
\hline \multicolumn{6}{|l|}{ Pohon } \\
\hline Api-api & Avicennia sp. & 360.00 & 1.00 & 13.82 & 256.50 \\
\hline Pidada & Sonneratia sp. & 26.67 & 0.13 & 1.61 & 27.52 \\
\hline Buta-buta & Excoecaria agallocha & 16.67 & 5.56 & 1.04 & 15.98 \\
\hline \multicolumn{6}{|l|}{ Pancang } \\
\hline Api-api & Avicennia sp. & 1133.33 & 0.47 & - & 153.00 \\
\hline Buta-buta & Excoecaria sp. & 373.33 & 0.13 & - & 47.00 \\
\hline \multicolumn{6}{|l|}{ Semai } \\
\hline Api-api & Avicennia sp. & 5500.00 & 0.40 & - & 200.00 \\
\hline \multicolumn{6}{|l|}{ RPH Singkil } \\
\hline \multicolumn{6}{|l|}{ Pohon } \\
\hline Api-api & Avicennia sp. & 600.00 & 0.97 & 18.96 & 300.00 \\
\hline \multicolumn{6}{|l|}{ Pancang } \\
\hline Api-api & Avicennia sp. & 2733.33 & 0.97 & - & 200.00 \\
\hline \multicolumn{6}{|l|}{ Semai } \\
\hline Api-api & Avicennia sp. & 416.67 & 0.97 & - & 200.00 \\
\hline
\end{tabular}


individu pohonnya semakin sedikit, dan hal tersebut terlihat pada grafik sebaran diameter di RPH Muara Gembong. sebaran diameter di RPH Singkil juga demikian, yaitu jumlah pohon menurun dengan bertambahnya kelas diameter.

\section{Struktur Vertikal}

Grafik struktur vertikal (Gambar 4) menunjukkan bahwa tegakan mangrove.

RPH Muara Gembong mempunyai empat stratum yaitu stratum A sebanyak 236.67 ind/ha, stratum B 23.33 ind/ha, stratum C 236.67 ind/ha dan stratumD 133.33 ind/ha. Namun, RPH Singkil hanya mempunyai 2 stratum yaitu stratum B 386.67 ind/ha dan stratum C $166.67 \mathrm{ind} / \mathrm{ha}$

\section{Regenerasi Hutan}

Regenerasi alami jenis-jenis mangrove di RPH Muara Gembong dan Singkil mempunyai jumlah yang berbeda untuk setiap jenis dan tingkat pertumbuhannya.

Secara umum, hutan mangrove adalah hutan yang mempunyai keanekaraagaman yang rendah apabila dibandingkan dengan ekosistem hutan lainya (Kusmana 1993). Berdasarkan hasil pengamatan, hutan mangrove di lokasi penelitian (RPH Muara Gembong dan RPH Singkil) terdiri dari tiga jenis yaitu api-api (Avicennia sp.), pedada ( Sonneratia sp.), buta-buta (Excoecaria agallocha.). Dua dari ketiga jenis tersebut masuk ke dalam kelompok mangrove mayor yaitu api-api (Avicennia sp.) dan pedada ( Sonneratia sp.). Kustanti (2011) menyatakan bahwa komponen penyusun kelompok mayor mempunyai taksonomi yang berbeda dengan tumbuhan daratan, dan biasanya membentuk tegakan murni tetapi tidak pernah meluas sampai ke

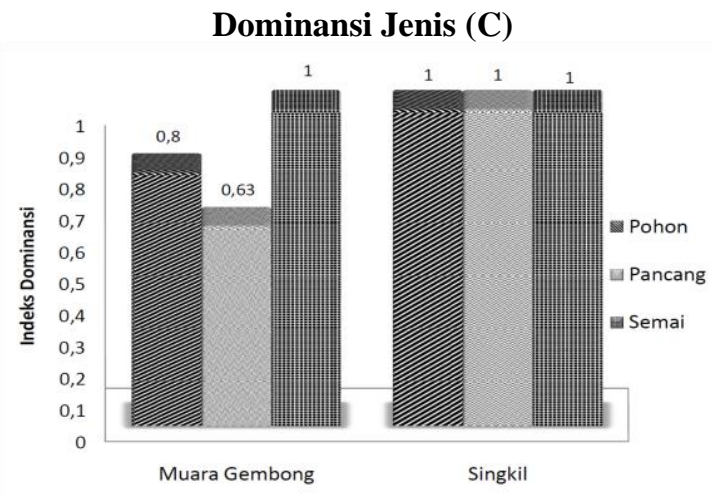

Gambar 2 Dominansi jenis pohon mangrove dan permudaannya pada setiap lokasi

Tabel 2 Nilai $\mathrm{H}, \mathrm{R}$ dan $\mathrm{E}$ pada setiap tingkat pertumbuhan mangrove di lokasi penelitian

\begin{tabular}{lrrr}
\hline \multicolumn{1}{c}{ Tingkat } & \multicolumn{2}{c}{ R' } & \multicolumn{2}{c}{ E } \\
\hline Pertumbuhan & $H^{\prime}$ & & \\
RPH Muara Gembong & & & \\
Pohon & 0.41 & 0.33 & 0.38 \\
Pancang & 0.56 & 0.14 & 0.81 \\
Semai & 0 & 0 & 0 \\
\hline RPH Singkil & & & \\
Pohon & 0 & 0 & 0 \\
Pancang & 0 & 0 & 0 \\
Semai & 0 & 0 & 0 \\
\hline
\end{tabular}

dalam komunitas daratan. Adapun jenis buta-buta (Excoecaria agallocha) termasuk ke dalam kelompok minor (vegetasi marjinal), yaitu jenis-jenis kelompok minor jarang membentuk tegakan murni dan biasanya bersekutu dengan mangrove yang tumbuh pada pinggiran dan mengarah darat.

Indeks dominansi (Gambar 2) menunjukkan bahwa telah terjadi penguasaan suatu jenis di lokasi penelitian (nilai C mendekati 1 pada semua tingkat pertumbuhan di kedua lokasi pengamatan). Hal ini dibuktikan juga dengan data (Tabel 1) bahwa ada jenis yang memiliki Indeks Nilai Penting yang tinggi yaitu jenis api-api (Avicennia sp.) sehingga jenis tersebut dominan dibandingkan dengan jenis yang lain. Jenis ini menjadi dominan karena ditemukan dalam jumlah yang banyak (nilai kerapatan besar dan mampu memanfaatkan sumberdaya yang ada sehingga lebih adaptif. Susanti (2014) menjelaskan bahwa jenis yang mempunyai INP tertinggi sampai dengan terendah menunjukkan urutan peranan atau penyesuaian jenis dalam persaingan pertumbuhan yang terjadi saat ini, sedangkan di masa mendatang akan tergantung pada sifat-sifat lain (intervensi dari luar) semasa pertumbuhan secara keseluruhan.

Nilai indeks keanekaragaman jenis pada kedua lokasi (Tabel 2) tergolong ke dalam kategori rendah karena nilai H' kurang dari 2. Hal tersebut menunjukkan bahwa fungsi dan proses ekologi di lokasi pengamatan telah terganggu, dibuktikan dengan adanya konversi hutan mangrove menjadi tambak oleh masyarakat di sekitar hutan. Menurut Ginting (2011) keanekaragaman jenis akan rendah dalam ekosistem-ekosistem yang secara fisik terkendali. Menurut Alikodra (1998) dalam Kiwa (2000) ekosistem alami akan membentuk suatu kesatuan yang mendekati stabil, akan tetapi manusia mengakibatkan keanekaragaman jenis, struktur dan komposisi tumbuhan hutan cenderung berubah menjadi komunitas yang homogen.

Nilai kemerataan jenis di RPH Muara Gembong pada tingkat pohon tergolong sedang $(\mathrm{E}=0.38)$, tingkat
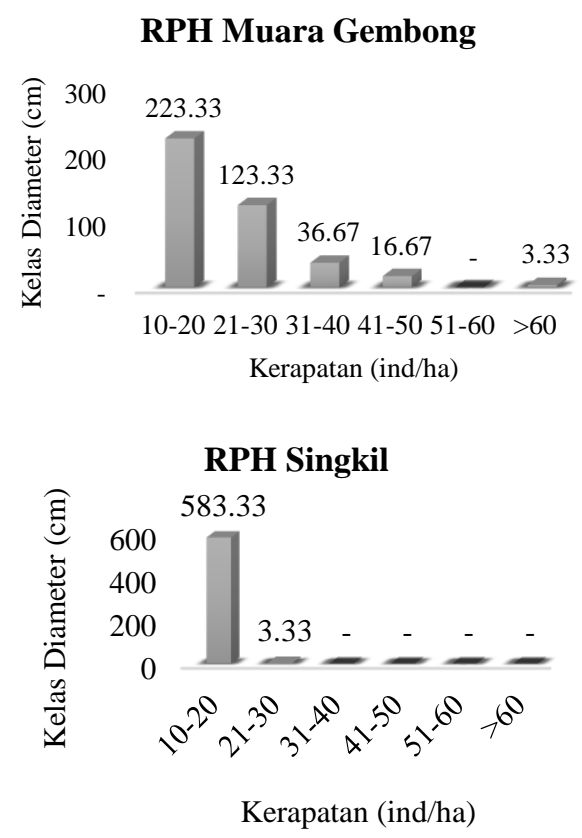

Gambar 3 Struktur horizontal tegakan hutan tingkat pohon di BKPH Ujung-Krawang 
pancang tergolong tinggi $(\mathrm{E}=0.81)$, dan tingkat semai tergolong rendah $(E=0)$. Adapun nilai kemerataan jenis di RPH Singkil untuk semua tingkat pertumbuhan tergolong rendah karena nilai $\mathrm{E}=0$. Nilai kemerataan jenis yang rendah menunjukkan bahwa penyebaran jumlah individu dalam suatu lokasi tidak sama sehingga ada kecenderungan jenis yang mendominasi. Indeks kekayaan jenis di kedua lokasi pengamatan pada setiap pertumbuhannya adalah rendah (nilai $\mathrm{R}<3.5$ ), karena jenis-jenis yang ditemukan sedikit yaitu hanya api-api (Avicennia sp.), pedada ( Sonneratia sp.), dan buta-buta (Excoecaria agallocha). Faktor-faktor yang mempengaruhi kekayaan jenis adalah kemampuan adaptasi, dan daya reproduksi tumbuhan.

Struktur horizontal hutan (Gambar 3) menunjukkan sebaran kelas diameter di hutan mangrove BKPH UjungKrawang semakin berkurang dari kelas diameter yang kecil ke kelas diameter yang besar sehingga terbentuk kurva "J terbalik" pada lokasi RPH Muara Gembong. Hasil penelitian yang sama juga ditemukan pada strukur hutan mangrove di Talindendang Besar Riau dan di Desa Pasar Banggi (Kusmana 2013 dan Wicaksono 2014). Fenomena ini disebabkan semakin bertambahnya waktu, individu-individu tersebut mengalami pertumbuhan yang memerlukan banyak energi sehingga terjadi persaingan, baik antara individu sejenis ataupun beda jenis dalam mendapatkan unsur hara yang cukup, dan pertahanan terhadap gangguan dari luar sehingga persaingan terus berlanjut dan mengakibatkan seleksi alam (Susanti 2014). Berbeda dengan kondisi sebaran diameter pada lokasi RPH Singkil yaitu, pohon terkonsentrasi pada kelas diameter 10 - 20 dan 21 - 30, sedangkan untuk kelas diameter lainnya tidak ditemukan. Hal ini dapat disebabkan terjadinya kematian pohon yang lebih banyak pada kelas diameter yang sedang sampai dengan yang besar dari pada kelas diameter yang kecil.

Menurut Kusmana (1993) stratifikasi mangrove biasanya bervariasi yaitu dari satu sampai empat dan akan semakin sedikit pada zona yang lebih jauh dari pantai. Stratifikasi tajuk hutan mangrove di BKPH Ujung-Krawang berkisar antara dua sampai empat stratum. Kerapatan pohon tertinggi lebih banyak ditemukan pada stratum C yaitu 236.67 pohon/ha (RPH Muara Gembong) dan stratum B yaitu 386.67 pohon/ha (RPH Singkil). Berdasarkan hasil pengamatan menunjukkan bahwa semakin sedikitnya pohon yang mencapai stratum A, hal ini dikarenakan individu membutuhkan waktu yang sangat lama dan persaingan yang tinggi dalam memperoleh air dan unsur hara maupun cahaya.

Menurut Indriyanto (2005) berjalan atau tidaknya proses regenerasi tegakan hutan dicerminkan oleh kondisi anakan pohon yang ada di kawasan hutan.
Berdasarkan Shankar (2001) status regenerasi jenis-jenis mangrove (Tabel 7) di RPH Muara Gembong yaitu good (baik) pada jenis api-api (Avicennia sp.), poor (rendah) pada jenis pedada (Sonneratia sp.), dan none (tidak ada regenerasi) pada jenis buta-buta (Excoecaria agallocha). Secara umum status regenerasi di lokasi tesebut adalah good (baik) karena jumlah semai lebih banyak dari pancang, dan jumah pancang juga lebih banyak dari pohon. Adapun status regenerasi di RPH Singkil termasuk ke dalam kategori fair (cukup) dan hanya disusun oleh satu jenis yaitu api-api (Avicennia sp.). Regenerasi alami jenis-jenis mangrove dipengaruhi oleh beberapa faktor biologi dan fisik yaitu stabilitas tanah dan genangan, elevasi tempat tumbuh, salinitas, dan ketersediaan propagul (Ebigwai dan Akomaye 2014, Krauss dan Allen 2003). Menurut Soud (2004) dalam Hamad et al. (2014) jumlah pohon dewasa yang rendah, ketiadaan semai, dan ketersediaan benih, dan pasang surut gelombang sangat berkontribusi terhadap rendahnya regenerasi hutan mangrove.

Tabel 5 menunjukkan bahwa kerapatan semai apiapi (Avicennia sp.) di RPH Singkil lebih sedikit dibandingkan tingkat pancang. Hal ini disebabkan, jenis tersebut merupakan jenis intoleran terhadap naungan (Rabinowitz 1978 dalam Thaxton et al. 2007). Ellison
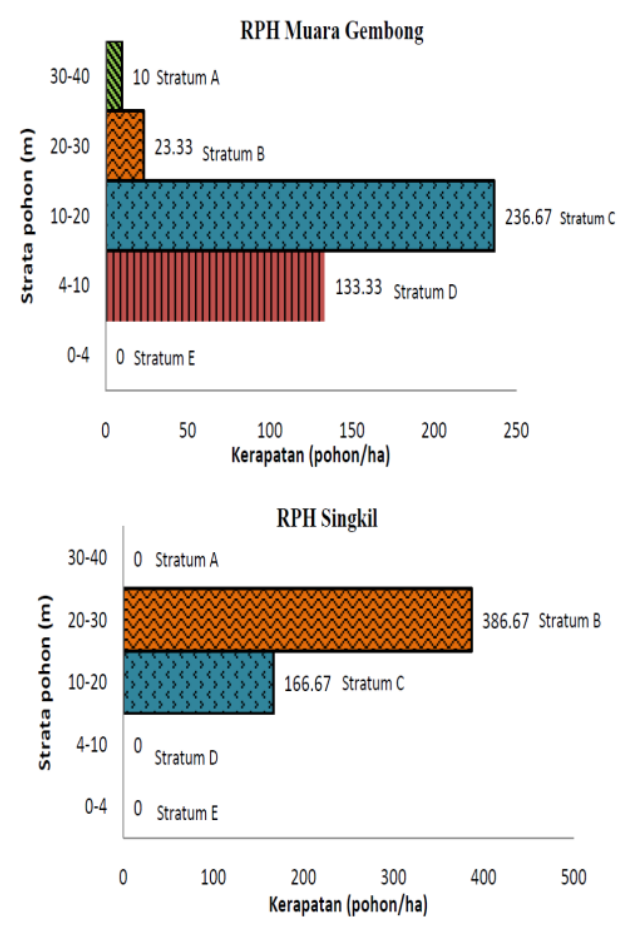

Gambar 4 Struktur vertikal tegakan hutan (stratifikasi tajuk) tingkat pohon di BKPH Ujung-Krawang

Tabel 5 Perbedaan regenerasi alami mangrove di lokasi penelitian di BKPH Ujung-Krawang

\begin{tabular}{llrrrr}
\hline \multicolumn{1}{c}{ Spesies } & \multicolumn{3}{c}{ Tingkat Pertumbuhan } \\
\hline Nama Lokal & Nama Ilmiah & Semai & Pancang & Pohon & Ket \\
\hline RPH Muara Gembong & & & & & \\
Api-api & Avicennia sp. & 5500 & 1133 & 360 & Fair \\
Pidada & Sonneratia sp. & 0 & 373 & 27 & Poor \\
Buta-buta & Excoecaria agallocha & 0 & 0 & 17 & None \\
& Jumlah & $\mathbf{5 5 0 0}$ & $\mathbf{1 5 0 6}$ & $\mathbf{4 0 4}$ & Fair \\
\hline RPH Singkil & & & & & \\
Api-api & Avicennia sp. & 417 & 2733 & 600 & Fair \\
& Jumlah & $\mathbf{4 1 7}$ & $\mathbf{2 7 3 3}$ & $\mathbf{6 0 0}$ & Fair \\
\hline
\end{tabular}


dan Farnsworth (1993) menyatakan bahwa jenis Avicennia sp. adalah jenis yang butuh cahaya, dan dibuktikan dengan tidak ditemukannya anakan dari Avicennia germinans di bawah tegakan di Bezile, dan diperkirakan bahwa jenis ini khusus pada daerah yang terbuka (ada gap), sehingga akan memanfaatkan keadaaan yang demikian untuk berkembang. Berbeda dengan hasil di RPH Muara Gembong bahwa anakan Avicennia sp. lebih banyak, dibandingkan dengan tingkat pertumbuhan yang lain. Pada jenis pedada (Sonneratia sp.) di lokasi RPH Muara Gembong tidak ditemukan anakan (semai) meskipun ada beberapa pohon dewasa. Hal tersebut juga terjadi hutan mangrove Mikronesia, dimana anakan jenis Sonneratia alba tidak ditemukan baik di bawah kanopi dan kanopi terbuka, dikarenakan jenis ini memproduksi benih yang kecil dan tidak seperti halnya buah vivipar pada jenis bakau lainya (Pinzon et al. 2003).

\section{SIMPULAN DAN SARAN}

\section{Simpulan}

Hutan mangrove di BKPH Ujung-Krawang memiliki keanekaragaman dan kekayaan jenis yang rendah. Jenis-jenis mangrove yang teridentifikasi untuk semua tingkat pertumbuhannya yang ditemukan ada tiga yaitu api-api (Avicennia sp.), pedada (Sonneratia sp.), dan buta-buta (Excoecaria agallocha), yang mana apiapi (Avicennia sp.) adalah jenis yang mendominasi di setiap lokasi pengamatan. Struktur horizontal hutan mangrove membentuk kurva "J terbalik" dan struktur vertikal hutan (stratifikasi tajuk) mempunyai dua sampai empat stratum yaitu stratum A, stratum B, stratum C dan stratum D. Untuk status regenerasi hutan mangrove di BKPH Ujung-Krawang dikategorikan baik (good) di RPH Muara Gembong dan cukup (fair) di RPH Singkil.

\section{Saran}

Hutan mangrove di BKPH Ujung-Krawang adalah kawasan lindung, namun telah terdegradasi akibat banyaknya aktivitas manusia. Untuk memperbaiki kondisi hutan tersebut sebaiknya perlu dilakukan rehabilitasi hutan.

\section{DAFTAR PUSTAKA}

Ellison AM, Farnsworth EJ. 1993. Seedling survivorship, growth, and response to disturbance in Belizean mangal. American Journal of Botani. Vol 80: 1137 -1145 .

Hamad HM, Mchenga ISS, Hamisi MI. 2014. Status of exploitation and regeneration of mangrove forests in Pemba Island, Tanzania. G.J.J.B., Vol 3 (1): 1218.

Indriyanto. 2005. Ekologi Hutan. Jakarta: PT Bumi Aksara.

Kiwa. 2000. Keanekaragaman dan potensi jenis tumbuhan penting di Cagar Alam Cibanteng DT II Sukabumi Jawa Barat [skripsi]. Bogor: Institut Pertanian Bogor.
Krauss KW, Allen JA. 2003. Factor influencing the regeneration of the mangrove Bruguiera gymnorrhiza (L.) Lamk. on a tropical Pasific Island. Forest Ecology and Management. Vol 176: $49-60$.

Kusmana C. 1993. A study on mangrove forest management based on ecological data in East Sumatra, Indonesia [disertasi]. Japan: Kyoto University.

Kusmana C. 1997. Metode Survey Vegetasi. Bogor: Institut Pertanian Bogor.

Kusmana C. 2014. Distribution and current status of mangrove forest in Indonesia. DI dalam: Hakeem KR, Ozturk M, editor. Mangrove Ecosystem of Asia. Springer: $52-59$.

Kusmana C, Wilarso S, Hilwan I, Pamoengkas P, Wibowo C, Tiryana T, Triswanto A, Yunafsi, Hamzah. 2003. Teknik Rehabilitas Mangrove. Bogor: Fakultas Kehutanan IPB.

Kustanti A. 2011. Manajemen Hutan Mangrove. Bogor: IPB Press.

Magurran AE. 1988. Ecological Diversity and Its Measurement. Australia: Croom Helm.

Mchenga ISS, Ali AI. 2014. Natural regeneration of mangrove in a degraded and non-degraded tropical forest of Zanzibar Island. Journanl of Global Biosciences. Vol 3 (1): 334 - 344.

Mirsa KC. 1980. Manual of Plant Ecology (second edition). New Delhi: Oxford and IBH Publishing $\mathrm{CO}$.

Pinzon ZS. Ewel KC, Putz FC. 2003. Gap formation and forest regeneration in Micronesian mangrove forest. Journal of Tropical Ecology. Vol 19; 143 153.

Setiadi D. 2004. Keanekaragaman spesies tingkat pohon di Taman Nasional Alam Ruteng, Nusa Tenggara Timur. Biodiversitas. 6: 118-122.

Shankar U. 2001. A case of high tree diversity in a Sal (Shorea robusta), dominated lowland forest of Eastern Himalaya: floristic composition, regenerasi and conservation. Current Science. 81 (7): 776-786.

Sherman RE, Fahey TJ, Battles JJ. 2000. Small-scale disturbance and regeration dynamics in a neotropical mangrove forest. Journal of ecology. Vol 88: $165-178$.

Sigiro ARM. 2013. Struktur tegakan dan regenerasi alami di Pulau Siberut, Sumatera Barat [skripsi]. Bogor: Institut Pertanian Bogor.

Soerianegara I, Indrawan A. 1998. Ekosistem Hutan Indonesia. Bogor: Fakultas Kehutanan IPB.

Susanti S. 2014. Komposisi jenis dan struktur tegakan regenerasi alami di Hutan Pendidikan Gunung Walat, Sukabumi [skripsi]. Bogor: Institut Pertanian Bogor.

Thaxton JM, DeWalt SJ, Platt WJ. 2007. Spatial patterns of regeneration after Hurricane Andrew in Two South Florida Fringe mangrove forests. Biological sciences. Vol 70 (2): 149 - 156.

Wicaksono FB. 2014. Komposisi jenis pohon dan struktur tegakan hutan mangrove di Desa Pasar Banggi Kabupaten Rembang Provinsi Jawa Tengah [skripsi]. Bogor: Institut Pertanian Bogor. 